ISSN: 2224-0616

Int. J. Agril. Res. Innov. Tech. 10(1): 97-101, June 2020

DOI: https://doi.org/10.3329/ijarit.v10i1.48100

\section{OPEN 2 ACCESS}

Available online at https://ijarit.webs.com https://www.banglajol.info/index.php/IJARIT

\title{
Response of maize (Zea mays L.) Ikenne variety to application of household urban solid wastes compost
}

\author{
K.K.A. Alate ${ }^{1}$, G. Mawussi ${ }^{*}$, K.D. Ayisah ${ }^{2}$ and K. Sanda ${ }^{1}$ \\ Received 18 April 2020, Revised 16 May 2020, Accepted 20 June 2020, Published online 30 June 2020
}

\begin{abstract}
A B S T R A C T
Soils fertility declining limits agricultural production in Togo where maize (Zea mays L.) is most cereal cropping and base staple food. Currently, mineral fertilizers are beyond the reach of farmers due to high price and limited availability. This study assessed the response of household urban wastes compost to the growth and yield of maize Ikenne variety. Experiments were performed in rainy season of years 2018 and 2019 at Teaching Research and Demonstration Farm of Agronomy School in University of Lome, Togo. Agronomic trials were set at randomized in complete block design with three replications, where control plots, compost plots at different doses and mineral fertilizers plots constituted the treatments. The growth parameters, including plant height, stem girth, leaf area and number of leaves per plant, were measured at the milky maize stage. The yield parameters, including length and girth of cob, thousand grains weight, grain yield and straw yield, were collected at harvesting. Data were statistically analyzed. The results showed three distinct homogeneous groups of treatments both for growth and yield parameters. Plots treated with compost at $30 \mathrm{t} \mathrm{ha}^{-1}$ and $40 \mathrm{t} \mathrm{ha} \mathrm{a}^{-1}$ constitute the best group, which differs significantly from the second group formed by plots treated with compost at $10 \mathrm{t} \mathrm{ha} \mathrm{h}^{-1}$ and $20 \mathrm{t} \mathrm{ha} \mathrm{i}^{-1}$ and mineral fertilizer plots. Control treatments constitute the last group. Growth and yield parameters values increase with compost dose. Far from being used alone in place of mineral conventional fertilizer, integrated fertilization based on combination of mineral fertilizer and compost of household urban wastes will investigated in maize cropping in southern Togo for optimal compost dose to recommend.
\end{abstract}

Keywords: Household waste compost, Maize Ikenne variety, Growth parameters, Grain yield.

${ }^{1}$ Department of Soil Sciences, Research Laboratory on Agroresources and Environmental Health, School of Agronomy University of Lome, BP 1515 Lome, Togo.

${ }^{2}$ Department of Plant Science and Improvement, School of Agronomy - University of Lome, BP 1515 Lome, Togo.

*Corresponding author’s email: gmawussi@gmail.com (G. Mawussi)

Cite this article as: Alate, K.K.A., Mawussi, G., Ayisah, K.D. and Sanda, K. 2020. Response of maize (Zea mays L.) Ikenne variety to application of household urban solid wastes compost. Int. J. Agril. Res. Innov. Tech. 10(1): 97-101. https://doi.org/10.3329/ijarit.v10i1.48100

\section{Introduction}

Maize (Zea mays L.) is principally a rainy season crop in Togo where soils fertility declining limits already agricultural productivity (Laba and Sogbedji, 2015). Currently, chemical fertilizers are beyond the reach of farmers due to high price and limited availability. This makes majority of households more vulnerable to the effects of climate change. In coastal zone of Togo, the red soils commonly called "Terre de Barre" constitute the main part of agricultural soils and are frequently cultivated without fallow and no organic restitution (use of crop residues as household fuel). These soils are overused and do not have the necessary time to replenish their organic matter stock. This can be explained by the excessive need of cultivable land due to the concern to multiply crop areas to ensure a minimum harvest faced to the rains irregularity due to climate change. In fact, demographic pressure and excess land use have led to a total depletion of agricultural soil, resulting in a decrease in the stock of organic carbon and a destructuring of the surface horizons, reducing mainly food crop production (maize, cassava, cowpea, tomato etc.). Food security will decrease due to a reduction in the length of rainfall season and a reduction of soil fertility. The smallholder farmers are facing famine and malnutrition. Based on previous studies, one possibility to restore these soils is the use of compost to increase organic matter that could reduce the process of degradation, raise the potential crop

International Journal of Agricultural Research Innovation \& Technology An open access article under (C) () 
production and allow a conservative agriculture. In fact, recent previous studies shown growth and yield response of maize (Zea mays L.) to variable doses of various composts (Laekemariam and Gidago, 2013; Muhammad and Jan, 2016; Coulibaly et al., 2019). Compost efficacy on agricultural productivity increase was widely demonstrated, but little is known about its influence on maize productivity in coastal zone of Togo.

This study explore organic fertilizer potential by evaluating agronomic performances response of maize (Zea mays L.) Ikenne variety to compost of household solid urban waste due to their availability as source of compostable organic matter.

\section{Materials and Methods}

\section{Study area and experimental design}

Field experiments were carried out at the University of Lome in the Teaching Research and Demonstration Farm of Agronomic School during two rainy seasons April to July in years of 2018 and 2019. The land had been cropped previously for many years. The soil type is a ferralsol locally called "Terre de Barre" that developed from a continental deposit (Saragoni et al., 1990). This soil is red, deep and suitable for almost all crops. Soil surface layer $(0-15 \mathrm{~cm})$ of experimental site was loamy sandy. For this study, the land was manually ploughed and divided into plots with plot area of $3.84 \mathrm{~m}^{2}(2.4 \mathrm{~m} \times 1.6 \mathrm{~m})$. Each plot was separated from the adjacent by $1 \mathrm{~m}$ interval while the replicates were separated by $1.5 \mathrm{~m}$ interval. The treatments were tested in randomized block design with three replication. There were six treatments per block where To refers to control plots without any compost use, while T10, T20, T30 and T40 refer to plots treated with compost at $10 \mathrm{t} \mathrm{ha}^{-1}, 20 \mathrm{t} \mathrm{ha}^{-1}, 30 \mathrm{t} \mathrm{ha}^{-1}$ and 40 t ha $^{-1}$ doses, respectively and $\mathrm{T}_{\mathrm{MF}}$ refers to plots treated with mineral fertilizers NPK $15-15^{-15}$ and Urea $(46 \% \mathrm{~N})$ applied respectively to $0.2 \mathrm{tha}^{-1}$ and $0.1 \mathrm{t} \mathrm{ha}^{-1}$ which are the national application doses of mineral fertilizers on maize. The compost used was produced with 70\% of household urban solid wastes collected from Agbalepedogan district in Lome mixed with 30\% poultry manure (Alate et al., 2019). It was applied at the beginning of maize cultivation. The compost was incorporated into surface layer $(\mathrm{o}-15 \mathrm{~cm})$.

\section{Crop management}

Maize variety Ikenne at short-cycle (90 days), most widely grown in Togo was used as a test plant. Maize grain was sown during the month of April and was harvested at maturity in July every year. Sowing was carried out manually according to $80 \mathrm{~cm} \mathrm{x} 40 \mathrm{~cm}$ cropping pattern i.e. seeding density of 62500 plants $\mathrm{ha}^{-1}$ at the rate of two plants per spot. It was performed on the same day for all treatments. Four seeds per spot were used to ensure the desired crop stand in each treatment and when plants attained four fully expanded leaves, thinning was conducted to adjust plant population. Each plot contained 3 rows of 8 plants per row i.e. 24 plants in total. The mineral fertilizers application was carried out as following: NPK 15-15-15 applied 8 days after sowing and urea $(46 \% \mathrm{~N})$ as a single dose at knee height stage i.e. 45 days after sowing and this only on plots treated with mineral fertilizers. These mineral fertilizers were applied at most $10 \mathrm{~cm}$ at the base of the plant and about $8 \mathrm{~cm}$ of depth. Two preventive phytosanitary treatments were performed respectively at 22 and 35 days after sowing to control the caterpillars of Spodoptera frugiperda, a pest of maize crops, which appeared in the West African countries in recent years.

\section{Growth and yield parameters data collection}

In this study, the growth parameters include plant height, stem girth, leaf area and number of leaves per plant while the yield parameters relate to length and girth of cob, thousand grains weight, grain yield and straw yield. The straw yield relate to the aerial parts and the roots of the plant. The leaf area was calculated as the product of leaf length and widest middle portion of the leaf and multiplied by the correction factor (0.75) (Elings, 2000). The harvesting technique consisted in detaching the cob from the spathes and keeping the spathes on the stems. Central row plants were used for data collection. Plant height, stem girth, leaf area and number of leaves per plant were measured in each plot at the milky maize stage. Length and girth of cob, thousand grains weight, grain yield and straw yield were recorded at harvesting. Grain yield was recorded by threshing the crop after 10-15 days of air-drying the cobs. The grain yield was adjusted at $14 \%$ grain moisture content. Thousand grain weight $(\mathrm{g}$ ) was taken from the grain lot of each treatment and weighed by using electronic digital balance. For recording straw yield $\left(\mathrm{t} \mathrm{ha}^{-1}\right)$ aerial parts and roots of plants of central row of each treatment were harvested at maturity. Bundles were tied, airdried and weighed by spring balance.

\section{Statistical analysis}

All data collected on various growth and yield parameters were grabbed into the Excel spreadsheet and subjected to analysis of variance (ANOVA) which was carried out with the CropStat software. Means comparisons between treatments were performed with Newman-Keuls Test at the threshold of $5 \%$. 


\section{Results}

The results on growth parameters, including plant height, stem girth, leaf area and number of leaves per plant, obtained from trials experimental are presented in Table 1. This table shows three distinct homogeneous groups of treatments for the plant height, stem girth, leaf area and number of leaves per plant. The plots treated with compost at dose of $30 \mathrm{t} \mathrm{ha}^{-1}$ and $40 \mathrm{t} \mathrm{ha}^{-1}$ constitute the best group, which differs significantly from the second group formed by the plots treated with compost at dose of $10 \mathrm{tha}^{-1}$ and $20 \mathrm{t} \mathrm{ha}^{-1}$ and the plots treated with mineral fertilizers. The control treatments constitute the third group (Table 1).
The results on yield parameters, including length and girth of cob, thousand grains weight, grain yield and straw yield, obtained from trials experimental are presented in Tables $2 \& 3$. These tables show three distinct homogeneous groups of treatments for the length and girth of cob, thousand grains weight, grain yield and straw yield. The plots treated with compost at dose of 30 $\mathrm{t} \mathrm{ha}^{-1}$ and $40 \mathrm{t} \mathrm{ha}^{-1}$ constitute the best group, which differs significantly from the second group formed by the plots treated with compost at dose of $10 \mathrm{t} \mathrm{ha}^{-1}$ and $20 \mathrm{t} \mathrm{ha}^{-1}$ and the plots treated with mineral fertilizer. The control treatments constitute the last group (Tables $2 \& 3$ ).

Table 1. Effects of fertilizer treatments on growth parameters of maize (Zea mays L.) Ikenne variety.

\begin{tabular}{|c|c|c|c|c|c|c|c|c|}
\hline \multirow[t]{2}{*}{ Treatments } & \multicolumn{2}{|c|}{ Plant height $(\mathrm{cm})$} & \multicolumn{2}{|c|}{ Stem girth $(\mathrm{cm})$} & \multicolumn{2}{|c|}{$\begin{array}{l}\text { Number of leaves } \\
\text { plant }^{-1}\end{array}$} & \multicolumn{2}{|c|}{$\begin{array}{l}\text { Leaf area plant }{ }^{-1} \\
\qquad\left(\mathrm{~cm}^{2}\right)\end{array}$} \\
\hline & 2018 & 2 & & & 2018 & 2019 & 2018 & 2019 \\
\hline To & 137.5 & & 0. & & $3 \cdot 5 \pm 1 \mathrm{a}$ & $1 \mathrm{a}$ & & \\
\hline T10 & $\mathrm{N}$ & & $3 b$ & 12 & $13.6 \pm 2 \mathrm{a}$ & 13.7 & $2 \mathrm{~b}$ & 56 \\
\hline T2O & $182.4 \pm 1 b$ & $191.5=$ & $12.4 \pm 2 b$ & $12.6=$ & $13.7=$ & $13 \cdot 9 \pm 2 \mathrm{a}$ & $1 \mathrm{~b}$ & $572 \pm 2 b$ \\
\hline T30 & $199.6 \pm 1 a$ & $204.6 \pm 1 a$ & $13.0 \pm 1 d$ & $14.0 \pm 1 d$ & $13.8 \pm 1 a$ & $14.0 \pm 1 \mathrm{a}$ & $698 \pm 1 a$ & $717 \pm 3 a$ \\
\hline 1 & $.3 \pm 1 a$ & $209 \cdot 5 \pm 1 a$ & $14.0 \pm 2 a$ & & $14.0 \pm$ & & $702 \pm 3 a$ & $729 \pm 2 a$ \\
\hline$T_{M F}$ & $181.2 \pm 1 b$ & $190.7 \pm 1 b$ & $12.3 \pm 2 b$ & $12.4 \pm 2 b$ & $13.6 \pm 2 a$ & $13.8 \pm 2 \mathrm{a}$ & $565 \pm 1 b$ & $569 \pm 1 b$ \\
\hline
\end{tabular}

In a column, treatment mean values followed by same letter are not significantly different at the threshold of $5 \%$. Each letter determines one distinct homogeneous group of treatments.

Table 2. Effect of fertilizer treatments on length of cob and girth of cob of maize (Zea mays L.) Ikenne variety.

\begin{tabular}{|l|cccc|}
\hline Treatments & \multicolumn{2}{c}{ Length of cob $(\mathrm{cm})$} & \multicolumn{2}{c|}{ Girth of cob $(\mathrm{cm})$} \\
& Year 2018 & Year 2019 & Year 2018 & Year 2019 \\
\hline To & $15.5 \pm 0.1 \mathrm{c}$ & $15.0 \pm 0.2 \mathrm{c}$ & $16.0 \pm 0.3 \mathrm{c}$ & $15.8 \pm 0.2 \mathrm{c}$ \\
\hline T1O & $17.0 \pm 0.1 \mathrm{~b}$ & $17.3 \pm 0.3 \mathrm{~b}$ & $18.2 \pm 0.1 \mathrm{~b}$ & $18.3 \pm 0.2 \mathrm{~b}$ \\
\hline T2O & $17.4 \pm 0.3 \mathrm{~b}$ & $17.6 \pm 0.1 \mathrm{~b}$ & $18.3 \pm 0.2 \mathrm{~b}$ & $18.5 \pm 0.1 \mathrm{~b}$ \\
\hline T30 & $19.0 \pm 0.2 \mathrm{a}$ & $19.3 \pm 0.3 \mathrm{a}$ & $21.2 \pm 0.2 \mathrm{a}$ & $21.5 \pm 0.3 \mathrm{a}$ \\
\hline T40 & $19.3 \pm 0.2 \mathrm{a}$ & $19.5 \pm 0.3 \mathrm{a}$ & $21.5 \pm 0.1 \mathrm{a}$ & $21.7 \pm 0.2 \mathrm{a}$ \\
\hline T & $17.3 \pm 0.3 \mathrm{~b}$ & $17.4 \pm 0.2 \mathrm{~b}$ & $18.3 \pm 0.1 \mathrm{~b}$ & $18.4 \pm 0.3 \mathrm{~b}$ \\
\hline
\end{tabular}

In a column, treatment mean values followed by same letter are not significantly different at the threshold of $5 \%$. Each letter determines one distinct homogeneous group of treatments.

Table 3. Effect of fertilizer treatments on thousand grains weight, grain yield and straw yield of maize (Zea mays L.) Ikenne variety.

\begin{tabular}{|c|c|c|c|c|c|c|}
\hline \multirow[t]{2}{*}{ Treatments } & \multicolumn{2}{|c|}{ Thousand grain weight (g) } & \multicolumn{2}{|c|}{ Grain yield (t ha-1) } & \multicolumn{2}{|c|}{ Straw yield $\left(\mathrm{t} \mathrm{ha}^{-1}\right)$} \\
\hline & Year 2018 & Year 2019 & Year 2018 & Year 2019 & Year 2018 & Year 2019 \\
\hline To & $201.5 \pm 0.2 c$ & $198.5 \pm 0.1 \mathrm{c}$ & $1.69 \pm 0.2 \mathrm{c}$ & $1.53 \pm 0.1 \mathrm{c}$ & $2.19 \pm 0.2 \mathrm{c}$ & $2.00 \pm 0.3 \mathrm{c}$ \\
\hline T10 & $249.7 \pm 0.1 b$ & $251.2 \pm 0.2 b$ & $3.14 \pm 0.3 b$ & $3.49 \pm 0.2 b$ & $4.29 \pm 0.2 b$ & $4.60 \pm 0.1 b$ \\
\hline T20 & $251.8 \pm 0.1 b$ & $255.3 \pm 0.3 b$ & $3.19 \pm 0.2 b$ & $3.55 \pm 0.3 \mathrm{~b}$ & $4.33 \pm 0.1 \mathrm{~b}$ & $4.69 \pm 0.2 b$ \\
\hline T30 & $309.5 \pm 0.2 \mathrm{a}$ & $315.4 \pm 0.3 \mathrm{a}$ & $4.55 \pm 0.1 \mathrm{a}$ & $4.59 \pm 0.2 \mathrm{a}$ & $5.10 \pm 0.3 \mathrm{a}$ & $5.38 \pm 0.1 \mathrm{a}$ \\
\hline $\mathrm{T} 40$ & $313.2 \pm 0.3 a$ & $319.3 \pm 0.2 \mathrm{a}$ & $4.59 \pm 0.2 \mathrm{a}$ & $4.70 \pm 0.1 \mathrm{a}$ & $5.29 \pm 0.2 \mathrm{a}$ & $5.45 \pm 0.1 \mathrm{a}$ \\
\hline $\mathrm{T}_{\mathrm{MF}}$ & $250.6 \pm 0.2 b$ & $253.8 \pm 0.1 \mathrm{~b}$ & $3.17 \pm 0.3 \mathrm{~b}$ & $3.50 \pm 0.1 b$ & $4.31 \pm 0.3 b$ & $4.64 \pm 0.2 b$ \\
\hline
\end{tabular}

In a column, treatment mean values followed by same letter are not significantly different at the threshold of 5\%. Each letter determines one distinct homogeneous group of treatments. 


\section{Discussion}

The homogeneous and identical groups of treatments for both growth parameters and yield parameters suggest effect relationship between growth and yield parameters. This explains that the yield parameters are the expression of growth parameters (Tables 1, 2 \& 3).

The means of plant height, stem girth and leaf area for all treatments increased with compost dose. The dose of $30 \mathrm{t} \mathrm{ha}^{-1}$ and $40 \mathrm{t} \mathrm{ha}^{-1}$ of compost gave the greatest means of plant height (199.6 to $209.5 \mathrm{~cm})$, stem girth $(13.8$ to $14.4 \mathrm{~cm})$ and leaf area $\left(698\right.$ to $729 \mathrm{~cm}^{2}$ ). These values were followed by those of $10 \mathrm{t} \mathrm{ha}^{-1}, 20 \mathrm{t} \mathrm{ha}^{-1}$ of compost and those of mineral fertilizers which ranged respectively from 180.6 to $191.5 \mathrm{~cm} ; 12.3$ to 12.6 $\mathrm{cm}$ and 560 to $572 \mathrm{~cm}^{2}$ while the least means of these parameters were recorded on control plots which ranged from 133.8 to $137.5 \mathrm{~cm} ; 10.0$ to 10.2 $\mathrm{cm}$ and 349 to $352 \mathrm{~cm}^{2}$, respectively. There was no significant difference $(p>0.05)$ in the number of leaves for the different treatments (Table 1).

The means of length and girth of cob, thousand grain weight, grain yield and straw yield for all treatments increased with compost dose. The dose of $30 \mathrm{tha}^{-1}$ and $40 \mathrm{tha}^{-1}$ of compost gave the greatest means of cob length (19.0 to $19.5 \mathrm{~cm}$ ), cob girth (21.2 to $21.7 \mathrm{~cm}$ ), thousand grain weight (309.5 to $319.3 \mathrm{~g}$ ), grain yield ( 4.55 to $4.70 \mathrm{t} \mathrm{ha}^{-1}$ ) and straw yield (5.10 to $5.45 \mathrm{t} \mathrm{ha}^{-1}$ ) (Tables $2 \& 3$ ). These values were followed by those of $10 \mathrm{t} \mathrm{ha}^{-1}$, $20 \mathrm{t} \mathrm{ha}^{-1}$ of compost and those of mineral fertilizers which ranged respectively from 17.0 to $17.6 \mathrm{~cm} ; 18.2$ to $18.5 \mathrm{~cm} ; 249$ to $255.3 \mathrm{~g} ; 3.14$ to $3.55 \mathrm{t} \mathrm{ha}^{-1} ; 4.29$ to $4.69 \mathrm{t} \mathrm{ha}^{-1}$ while the least means of these parameters were recorded on control plots which ranged from 15.0 to $15.5 \mathrm{~cm}$; 15.8 to $16.0 \mathrm{~cm} ; 198.5$ to $201.5 \mathrm{~g} ; 1.53$ to $1.69 \mathrm{t} \mathrm{ha}^{-1}$ and 2.00 to $2.19 \mathrm{t} \mathrm{ha}^{-1}$, respectively (Tables $2 \& 3$ ).

The results pertaining to the plant height, stem girth, leaf area and number of leaves per plant revealed that application of compost in this study influenced significantly growth parameters of maize Ikenne variety (Table 1). Similar results were reported by Coulibaly et al. (2019) who stated that the tallest growth parameters of maize were obtained with compost of pig. Our results stand in harmony with those found by Muhammad and Jan (2016) who revealed that compost amendment enhanced maize crop yield and yield components with or without fertilizer-N. Although, variations in growth parameters of maize due to treatments were observed, the plant height, stem girth and leaf area of plants from plots treated with compost at doses of $10 \mathrm{t} \mathrm{ha}^{-1}$ and $20 \mathrm{t} \mathrm{ha}^{-1}$ were statistically at par with plots treated with mineral fertilizers (Table 1). This might be due to the availability of nutrient elements required for growth and development of plant in soil of plots treated with compost at these doses (10 tha ${ }^{-1}$ and $20 \mathrm{t} \mathrm{ha}^{-1}$ ).

The stem girth of maize is an important criterion, which determines its strength and ability to resist lodging. In this study, it increases with increasing compost dose. This suggests that compost use in maize cropping at a suitable dose will contributes to reduce stalk lodging. The photosynthetic activity in the leaf is the driver of crop yield and is dependent on leaf area (Laekemariam and Gidago, 2012). Any treatment pertaining to increasing leaf area is thus likely to contribute towards raising crop growth and crop yield. This was observed through the results recorded on leaf area and cob size (Tables $1 \& 2$ ). The mean of cob length and girth of maize Ikenne variety increased with increasing the height of plant, girth of stem and leaf area of plant. This means that growth parameters affected significantly cob size. This is confirming the findings of Laekemariam and Gidago (2012) and Coulibaly et al. (2019) after compost application.

Thousand grains weight constitutes a significant factor in economic yield determination (Muhammad and Jan, 2016). The mean maize thousand grains weight from our trials experimental was significantly affected by application of compost and mineral fertilizers in comparison with control. The minimum in thousand grains weight from control plots might be attributed to deficiency of macronutrients throughout the plant life especially at the time of flowering and seed setting. The mean maize grain yield from compost treatments and chemical fertilizer treatments was highly superior to that of the control treatments (Table 3). These results are in line with the findings of Laekemariam and Gidago (2013) who demonstrated the growth and yield response of maize to variable rates of compost in Wolaita in Southern Ethiopia. An increase in maize yield related to compost application compared to the control suggest that compost might contain more essential available nutrients for maize productivity (Adjei-Nsiah, 2012).

Straw yield can be considered as the whole harvesting residues resulting from many morphological and physiological processes of growth and development of crop. In this study, straw yield increase with increasing level of compost applied. The increase in straw yield of maize could reflect the better growth and harmonious development of the plants due to availability of nutrients throughout the growing period related to compost effect. Growth and yield response of maize Ikenne variety to compost of household solid urban wastes during the two 
years of trial agronomics may be explained by soil organic matter increasing and increase of microbial activity in the soil with concomitant increased availability of nitrogen $(\mathrm{N})$, phosphorus $(\mathrm{P})$ and potassium $(\mathrm{K})$ necessary to maize plants development (Ojeniyi et al., 2010).

\section{Conclusion}

It can be concluded that household urban solid waste compost influenced maize growth and yield parameters in rainy season in local conditions. The compost doses of $10 \mathrm{t} \mathrm{ha}^{-1}, 20 \mathrm{t} \mathrm{ha}^{-1}, 30 \mathrm{t} \mathrm{ha}^{-1}$ and $40 \mathrm{t} \mathrm{ha}^{-1}$ improved proportionally the growth and yield parameters. These results suggest that the application of household urban solid waste compost at the minimum dose of $10 \mathrm{t} \mathrm{ha}^{-1}$ could improve growth and the yield of maize. Far from being used alone in place of mineral conventional fertilizers, further works will investigate integrated fertilization based on combination of mineral fertilizers and composts of household solid urban wastes in maize cropping in coastal zone of Togo for reliable recommendations' formulation.

\section{Acknowledgements}

The authors thank Laboratory of Management, Treatment and Value of Waste, University of Lomé (GTVD/UL), Laboratory of Research on Agroresources and Environmental Health of the Higher Agronomy School of University of Lome, and Non-Governmental Organization ENPRO (Naturel Ecosystem Clean), for their cooperation in conducting the study.

\section{References}

Adjei-Nsiah, S. 2012. Response of maize (Zea mays L.) to different rates of palm bunch ash application in the semi-deciduous forest agro-ecological zone of Ghana. Appl. Environ Soil Sci. Article ID 870948 1-5. https://doi.org/10.1155/2012/870948

Alate, K.K.A., Mawussi, G., Ayisah, K.D. and Sanda, K. 2019. Agronomic potential value of household urban solid wastes by composting and composts quality assessment. Int. J. Agril. Res. Innov. Tech. 9(2): 1-8. https://doi.org/10.3329/ijarit.v9i2.45403

Coulibaly, S.S., Kouassi, K.I., Koffi, K.K. and Zoro, B.I.A. 2019. Effect of compost from different animal manures on maize (Zea mays) growth. J. Exptl. Biol. Agric. Sci. 7(2): 178185.

Elings, A. 2000. Estimation of leaf area in tropical maize. Agron. J. 92: 436-444. https://doi.org/10.2134/agronj2000.923436x

Laba, B.S. and Sogbedji, J.M. 2015. Identification of land degradation and climate change resilient soil and crop management strategies for maize production on West African ferralsols. Int. Invention. J. Agric. Soil Sci. 3(2): 13-20.

Laekemariam, F. and Gidago, G. 2012. Response of maize (Zea mays L.) to integrated fertilizer application in Wolaita, South Ethiopia. Adv. in Life Sci. Tech. 5: 21-30.

Laekemariam, F. and Gidago, G. 2013. Growth and yield response of maize (Zea mays L.) to variable rates of compost and inorganic fertilizer integration in Wolaita, Southern Ethiopia. American J. Plant Nutri. Ferti. Tech. 3: 43-52. https://doi.org/10.3923/ajpnft.2013.43.52

Muhammad, Z. and Jan, M.T. 2016. Evaluation of different composts composition on the yield and yield components of maize (Zea mays L.). Sarhad J. Agric. 32(3): 156-167. https://doi.org/10.17582/journal.sja/2016.32.3.1 56.167

Ojeniyi, S.O., Awanlemhen, B.C. and Adejoro, S.A. 2010. Soil plant nutrients and maize performance as influenced by oil palm bunch ash plus NPK fertilizer. J. American Sci. 6(12): 456-460.

Saragoni, H., Poss, R. and Olivier, R. 1990. Dynamique et lixiviation des éléments minéraux dans les terres de barre du Sud du Togo. Agron. Trop. 45(4): 259-273. https://agritrop.cirad.fr/405837 